International Journal of Environmental Research and

Public Health

ISSN 1660-4601

www.mdpi.com/journal/ijerph

Article

\title{
Relationship between the Concentrations of Heavy Metals and Bioelements in Aging Men with Metabolic Syndrome
}

\author{
Iwona Rotter ${ }^{1}$, Danuta Kosik-Bogacka ${ }^{2, *}$, Barbara Dołęgowska ${ }^{3,4}$, Krzysztof Safranow ${ }^{5}$, \\ Anna Lubkowska ${ }^{6}$ and Maria Laszczyńska ${ }^{7}$
}

1 Independent Laboratory of Medical Rehabilitation, Pomeranian Medical University, Żołnierska 54, 71-210 Szczecin, Poland; E-Mail: iwrot@wp.pl

2 Department of Biology and Medical Parasitology, Pomeranian Medical University, Powstańców Wielkopolskich 72, 70-111 Szczecin, Poland; E-Mail: kodan@pum.edu.pl

3 Department of Laboratory Diagnostics, Pomeranian Medical University, Powstańców Wielkopolskich 72, 70-111 Szczecin, Poland; E-Mail: barbara.dolegowska@pum.edu.pl

4 Department of Laboratory Diagnostics, Poznan University of Medical Sciences, Szamarzewskiego 82/84, 60-569 Poznań, Poland; E-Mail: barbara.dolegowska@pum.edu.pl

5 Department of Biochemistry and Medical Chemistry, Pomeranian Medical University, Powstańców Wielkopolskich 72, 70-111 Szczecin, Poland; E-Mail: chrissaf@mp.pl

6 Department of Physical Medicine and Functional Diagnostics, Pomeranian Medical University, Żołnierska 54, 71-210 Szczecin, Poland; E-Mail: annalubkowska@gmail.com

7 Department of Histology and Developmental Biology, Pomeranian Medical University, Żołnierska 48, 71-210 Szczecin, Poland; E-Mail: maria@laszczynska.pl

* Author to whom correspondence should be addressed; E-Mail: kodan@pum.edu.pl; Tel.: +48-914-661-672; Fax: +48-914-661-671.

Academic Editor: Paul B. Tchounwou

Received: 6 February 2015 / Accepted: 30 March 2015 / Published: 10 April 2015

\begin{abstract}
Heavy metals may exacerbate metabolic syndrome (MS) but abnormal serum concentrations of bioelements may also co-exist with MS. The primary aim of the study was to assess the relationship of blood heavy metal and bioelement concentrations and MS, in men aged 50-75 years. Heavy metals - lead $(\mathrm{Pb})$, cadmium $(\mathrm{Cd})$, mercury $(\mathrm{Hg})$, arsenic (As), tungsten $(\mathrm{W})$, Macroelements - magnesium $(\mathrm{Mg})$ and calcium $(\mathrm{Ca})$, and microelements - iron $(\mathrm{Fe})$, zinc $(\mathrm{Zn})$ copper $(\mathrm{Cu})$, chromium $(\mathrm{Cr})$, molybdenum $(\mathrm{Mo})$, selenium $(\mathrm{Se})$ and manganese (Mn), body mass index (BMI), waist to hip ratio (WHR), abdominal
\end{abstract}


circumference (AC) and blood pressure (BP), total cholesterol (TCh), high-density lipoprotein (HDL), low-density lipoprotein (LDL), triglyceride (TG), fasting plasma glucose (FPG), insulin, and Homeostasis Model Assessment-Insulin resistance (HOMA-IR). The men with MS showed statistically significant higher $\mathrm{Zn}$ and lower Mg concentrations. Those with diabetes had higher $\mathrm{Ca}$ concentration and lower $\mathrm{Mg}$ concentration. $\mathrm{Cr}$ and $\mathrm{Mn}$ concentrations were significantly higher in obese men. The participants with hypertension had lower $\mathrm{Mg}$ concentration. We found statistically significant positive correlations (W-TCh, W-LDL, Mg-TCh, Mg-LDL, Ca-TCh, Ca-LDL, Ca-insulin, Ca-HOMAR-IR, Zn-TG, Zn-insulin, Zn-HOMA-IR, Cu-BP systolic, Mn-BMI, Mn-AC, Mn-WHR, Mn-insulin, Mn-HOMA-IR, Se-TCh, Se-LDL, Se-TG, Se-insulin, Se-HOMA-IR, Cr-TCh, Cr-HDL, Cr-LDL, Cr-TG) and negative correlations (Cd-insulin, Hg-WHR, W-insulin, W-HOMA-IR, Mg-BMI, Mg-AC, Mg-WHR, Mg-BP systolic, Mo-insulin, Mn-HDL). Tungsten may contribute to lipid disorders. Magnesium appears to play the protective role in the occurrence of metabolic disorders. Microelements $\mathrm{Mn}, \mathrm{Cr}$ and Se may intensify MS.

Keywords: metabolic syndrome; heavy metals; magnesium; tungsten; bioelements

\section{Introduction}

MS is a grouping of factors that increases the risk for the development and progression of type II diabetes mellitus (TIIDM) and cardiovascular disease [1]. The criteria for identifying MS include three of five markers: abdominal obesity, impaired carbohydrate metabolism, high blood pressure and dyslipidemia (elevated levels of triglycerides and decreased levels of high-density lipoprotein (HDL)). In developed countries, MS occurs in approximately $25 \%$ of the middle-aged population [2]. In Poland, this problem affects $28.4 \%$ of men aged $40-59$ years and $34.5 \%$ of men aged $60-74$ [3].

Environmental exposure to heavy metals commonly used in industry, including lead $(\mathrm{Pb})$, arsenic (As, a metalloid) and cadmium (Cd), increases the occurrence of diabetes and cardiovascular diseases [4-7]. Although tungsten (W) is considered to be a relatively non-toxic metal, it is known for its thrombogenic and proinflammatory action [8]. Its effects are also antagonistic to copper $(\mathrm{Cu})$. Tungsten may interfere with the biological effects of molybdenum, an essential trace metal found of several enzymes $[9,10]$. On the other hand, some studies in animal models demonstrate that $\mathrm{W}$ intake contributes to weight loss and improves insulin sensitivity $[11,12]$, although this weigh loss may be secondary to low grade toxicity. However, research in this area is scarce.

More commonly, the relationship between the prevalence of MS and the concentrations of macro- and micro-elements vital to life such as magnesium $(\mathrm{Mg})$, iron (Fe), zinc $(\mathrm{Zn}), \mathrm{Cu}$, selenium (Se), manganese $(\mathrm{Mn})$ and chromium $(\mathrm{Cr})$. Magnesium is a cofactor of many enzymes involved in the metabolism of lipids and carbohydrates, and hypomagnesaemia often coexists with MS, TIIDM, insulin resistance and hypertension (HA) [13-16], although the role of $\mathrm{Mg}$ supplementation in the normalization of the metabolic profile is equivocal [13,17-18]. Many studies confirm the link between high Fe concentration and the presence of individual components of MS [19-23]. Research on relationships between $\mathrm{Zn}$ and $\mathrm{Cu}$ concentrations and the occurrence of TIIDM show that in type 2 
diabetics, $\mathrm{Zn}$ concentration is significantly lower and $\mathrm{Cu}$ concentration is elevated compared to healthy participants [24,25]. Lower serum $\mathrm{Cu}$ may be associated with development of diabetic complications [26], while $\mathrm{Zn}$ supplementation may prevent the development of MS and diabetes [27]. It still has not been explained whether there is a clear relationship between the concentrations of these elements and MS, TIIDM and TIIDM complications [27].

Selenium exhibits antioxidant activity but its impact on metabolic disorders is inconclusive. Some researchers suggest that the antioxidant properties of Se may prevent metabolic disorders [28,29]. On the other hand, there exists data which indicates the negative impact of Se on some parameters of lipid and carbohydrate metabolism [30,31] so there may be a narrow window of optimum concentration. Manganese and chromium are components or activators of some enzymes, mostly antioxidants, and play an important role in the metabolism of carbohydrates and lipids, leading to the normalization of the synthesis and secretion of insulin and, therefore, having protective effects against the occurrence of MS [32,33].

The aim of this study was to assess the relationship between the concentrations of heavy metals $(\mathrm{Pb}, \mathrm{Cd}$, mercury- $\mathrm{Hg}, \mathrm{As}, \mathrm{W})$ and bioelements $(\mathrm{Mg}$, calcium- Ca, $\mathrm{Fe}, \mathrm{Zn}, \mathrm{Cu}, \mathrm{Cr}, \mathrm{Mo}, \mathrm{Se}, \mathrm{Mn})$ and the prevalence of MS and concomitant metabolic disorders, such as diabetes and obesity, in men aged between 50-75 years. Furthermore, the aim was to assess the relationship between the concentrations of heavy metals and bioelements and the lipid parameters concentrations, including total cholesterol (TCh), high-density lipoprotein (HDL), low-density lipoprotein (LDL), triglyceride (TG), carbohydrate metabolism parameters: fasting plasma glucose (FPG), level, insulin, insulin resistance (IR), as well as anthropometric parameters: Body Mass Index (BMI), waist to hip ratio (WHR), abdominal circumference (AC) and blood pressure (BP).

Older men in Poland have a higher likelihood of working in or near to heavy industrialization at times when pollution was not well controlled, and are generally at higher risk of MS rather than women. Given the fact that oxidative stress plays a role in the pathogenesis of MS [34-36], we examined the hypothesis that higher concentrations of toxic metals and abnormal concentrations of bioelements may disorders contribute to MS, particularly in aging men.

\section{Material and Methods}

The study comprised 313 men aged 50-75 years (mean age 61.3 years \pm 6.3 ) who had volunteered after receiving information about the study from family doctors at primary health care centres operating in Szczecin (north-western Poland). Smokers were included but men were excluded if they were receiving steroids or neuroleptics, were hypothyroid or hyperthyroid, and were undergoing cancer treatment. The men were not professionally or knowingly exposed to toxic levels of heavy metal. The men were not professionally or knowingly exposed to toxic levels of heavy metals and a medical questionnaire showed that none of the participants exceeded a daily alcohol intake of $40 \mathrm{~g}$. According to the WHO guidelines, exceeding this threshold in men is considered to be hazardous to health. The subjects were men from north-western Poland, which is not an industrialized area. The men did not work in industry, and most of them were pensioners, while the others worked in services.

This study conforms to the principles outlined in The Declaration of Helsinki as revised in 2008. The study ran from March 2013 to February 2014 and was approved by the Bioethics Committee of 
the Pomeranian Medical University in Szczecin (KB-0012/159/12). The participants who participated in the study were informed about the course of the study gave informed consent (written) to take part in it.

The men were surveyed for demographic data and the presence of chronic diseases. The blood pressure, weight, height, waist and hip circumference were measured. Body mass index (BMI) and waist-to-hip ratio (WHR) were calculated. Body weight of the participants averaged $87 \pm 15 \mathrm{~kg}$, BMI $28.3 \pm 7.7 \mathrm{~kg} / \mathrm{m}^{2}$, waist $102 \pm 12 \mathrm{~cm}$ and WHR $0.99 \pm 0.06$. The average systolic blood pressure was $135 \pm 20 \mathrm{mmHg}$ and diastolic blood pressure was $84 \pm 20 \mathrm{mmHg}$.

Fasting venous blood samples were taken from mornings, between 7.30 a.m., to 9.00 a.m. For biochemical analyses and the determinations of bioelements ( $\mathrm{Mg}, \mathrm{Fe}, \mathrm{Zn}, \mathrm{Cu}, \mathrm{Ca}, \mathrm{Mo}, \mathrm{Cr}, \mathrm{Se}, \mathrm{Mn}$ ), blood was collected into a tube containing a coagulator and gel separator, and was then centrifuged. To determine the concentration of heavy metals $(\mathrm{Pb}, \mathrm{Cd}, \mathrm{Hg}, \mathrm{As}, \mathrm{W})$, blood was collected into tubes with an anticoagulant (EDTA). We stored the sampled blood and serum at $-70{ }^{\circ} \mathrm{C}$.

In order to determine the concentration of toxic metals and bioelements, we used inductively coupled argon plasma optical emission spectrometry (ICP OES), using an Optima 2000 DV camera manufactured by Perkin Elmer (Norwalk, CT, USA), following decomposition and removal of organic matrix from the blood samples in a microwave mineralizer manufactured by Anton Paar (Vienna, Austria). After the addition of $\mathrm{HNO}_{3}$ and $\mathrm{H}_{2} \mathrm{O}_{2}$, we placed the blood or serum samples in a microwave oven which allowed a continuous monitoring of temperature and pressure in each vessel. Sample mineralization was performed according to the "Meat" procedure. To calibrate the method, we used certified multi-element standard CERTIPUR ${ }^{\circledR}$ ICP multi-element standard VIII (Merck KGaA, Darmstadt, Germany). The standard solutions were supplemented with mineralization reagents at concentrations equal to those in the mineralized samples. The emitted radiation intensity was always measured using the longer axial (along the plasma) optical path of the spectrometer. In order to verify the accuracy of the analytical method, we made the determinations of two certified reference materials (whole blood and serum): Seronorm ${ }^{\mathrm{TM}}$ Trace Elements of Whole Blood L-2 and Trace Elements Seronorm $^{\mathrm{TM}}$ Serum L-2, produced by SERO AS (Billingstad, Norway). The levels of individual elements in the blood and serum are shown in Table 1.

We determined the concentrations of FPG, TCh, TCh, HDL, LDL and TG in the samples, employing the spectrophotometric method and reagent kits (Biolabo, Aqua-Med, Łódź, Poland). Insulin levels were determined by ELISA method using reagent kits (DRG Medtek, Warsaw, Poland). We calculated insulin resistance IR in patients without diabetes according to the formula: HOMA-IR $=$ FPG $(\mathrm{mmol} / \mathrm{L}) \times$ fasting insulin levels $(\mu \mathrm{U} / \mathrm{mL}) / 22.5$.

Metabolic syndrome (MS), which was diagnosed according to the 2005 criteria of the International Diabetes Federation (IDF) [37]. According to IDF guidelines for the diagnosis of MS in men in Europe, MS is indicated by an abdominal circumference $\geq 94 \mathrm{~cm}$, and two of the following abnormalities: HDL cholesterol $<40 \mathrm{mg} / \mathrm{dL}(1.03 \mathrm{mmol} / \mathrm{L})$ or the treatment of dyslipidemia, $\mathrm{TG} \geq 150 \mathrm{mg} / \mathrm{dL}(1.7 \mathrm{mmol} / \mathrm{L})$ or the treatment of dyslipidemia, FPG $\geq 100 \mathrm{mg} / \mathrm{dL}(5.6 \mathrm{mmol} / \mathrm{L})$ or the treatment of diabetes, systolic $\mathrm{BP} \geq 130 \mathrm{mmHg}$, diastolic $\mathrm{BP} \geq 85 \mathrm{mmHg}$ or antihypertensive treatment. 
Table 1. The concentrations of elements in the whole blood and serum of participants.

\begin{tabular}{ccc}
\hline Material & Element & Measurement $(\mathbf{m c g} / \mathbf{L})$ and SD \\
\hline \multirow{4}{*}{ Whole blood } & $\mathrm{Pb}$ & $310.4 \pm 4.3$ \\
& $\mathrm{Cd}$ & $5.60 \pm 0.34$ \\
& $\mathrm{Hg}$ & $16.7 \pm 1.4$ \\
& $\mathrm{As}$ & $15.3 \pm 1.1$ \\
& $\mathrm{~W}$ & $6.01 \pm 0.1$ \\
$\mathrm{Mg}$ & $40.8 \pm 1.0$ \\
& $\mathrm{Fe}$ & $2.18 \pm 0.07$ \\
& $\mathrm{Ca}$ & $136.3 \pm 3.5$ \\
& $\mathrm{Cu}$ & $3289.0 \pm 55.0$ \\
& $\mathrm{Zn}$ & $2351.0 \pm 42.0$ \\
& $\mathrm{Se}$ & $156.9 \pm 5.1$ \\
& $\mathrm{Mo}$ & $0.89 \pm 0.06$ \\
& $\mathrm{Mn}$ & $20.0 \pm 1.4$ \\
& $\mathrm{Cr}$ & $4.76 \pm 0.38$ \\
\hline
\end{tabular}

Statistical analysis was carried out using the program Statistica PL (Statsoft, Tulsa, OK, USA). The distribution normality was examined using a Shapiro-Wilk test. Due to the non-parametric distribution of results, intergroup comparisons were performed using the Mann-Whitney $U$ test. The correlations between the analyzed variables were calculated with Spearman's rank correlation coefficient $\left(\mathrm{r}_{\mathrm{s}}\right)$. In addition, in order to assess the possible impact of cigarette smoking on the incidence of MS in the study group, a logistic regression model was used.

\section{Results}

In the group of 313 men, TCh concentrations were in the range $2.48-10.76 \mathrm{mmol} / \mathrm{L}$ ) (mean 5.66 \pm 1.47), HDL 0.49-2.46 mmol/L (1.27 \pm 0.31$), \quad$ LDL $0.52-8.84 \mathrm{mmol} / \mathrm{L}$ (mean $3.67 \pm 1.40)$, and TG $0.42-6.56 \mathrm{mmol} / \mathrm{L}(1.63 \pm 0.95)$. The parameters of carbohydrate metabolism were determined in 256 participants without diabetes. The FPG concentrations ranged 2.94-13.17 $\mathrm{mmol} / \mathrm{L}$ (mean $5.94 \pm 1.22$ ), the mean insulin level was $14.8 \pm 7.65 \mu \mathrm{LU} / \mathrm{mL}(1.22-55.42$ ), and HOMA-IR ranged 0.31-15.81 (mean $3.95 \pm 2.22$ ). MS was determined in 161 men (51.44\%) and TIIDM in $17.57 \%$ of the men $(n=55)$, hypertension in $54.63 \%(n=171)$, overweight (BMI: $25-29.9$ $\left.\mathrm{kg} / \mathrm{m}^{2}\right)$ in $164(52.39 \%)$, obesity $\left(\mathrm{BMI} \geq 30 \mathrm{~kg} / \mathrm{m}^{2}\right)$ in $27.79 \%$ of the men $(\mathrm{n}=87)$. Statins were being taken by $49(15.65 \%)$ of the men. All participants with hypertension were being treated with antihypertensive drugs.

Table 2 presents the concentrations of heavy metals $(\mathrm{Pb}, \mathrm{Cd}, \mathrm{Hg}$, As and $\mathrm{W})$ and bioelements $(\mathrm{Mg}, \mathrm{Ca}$, $\mathrm{Fe}, \mathrm{Zn}, \mathrm{Cu}, \mathrm{Cr}, \mathrm{Mn}, \mathrm{Mo}, \mathrm{Se}$ ) in men with MS and without MS. Only Mg concentration was significantly lower and $\mathrm{Zn}$ concentration significantly higher in men with MS compared to those without MS. There were no other statistically significant differences in the concentrations of heavy metals or bioelements between the groups.

Table 3 presents the concentrations of heavy metals and bioelements in men with TIIDM. Only $\mathrm{Mg}$ concentration was statistically significantly lower and $\mathrm{Ca}$ concentration statistically significantly higher in the diabetic patients compared to the healthy participants. 
Table 2. Concentrations of heavy metals and bioelements in men with and without metabolic syndrome (MS) (AM, arithmetic mean; SD, standard deviation; Med-median; $p$ : probability for trend).

\begin{tabular}{|c|c|c|c|c|c|c|c|}
\hline \multirow{2}{*}{ Metal } & \multicolumn{3}{|c|}{$\operatorname{MS}(n=161)$} & \multicolumn{3}{|c|}{ Without MS $(n=152)$} & \multirow{2}{*}{$p$} \\
\hline & AM (SD) & Med & Range & AM (SD) & Med & Range & \\
\hline \multicolumn{8}{|c|}{ Heavy Metals } \\
\hline $\mathrm{Pb}(\mathrm{mcg} / \mathrm{L})$ & $75.17(21.4)$ & 73.00 & $24.3-161.5$ & $73.82(21.7)$ & 71.05 & $28.0-138.5$ & 0.46 \\
\hline $\mathrm{Cd}(\mathrm{mcg} / \mathrm{L})$ & $1.55(0.32)$ & 1.59 & $0.59-3.06$ & $1.53(0.34)$ & 1.53 & $0.62-2.35$ & 0.41 \\
\hline As $(\mathrm{mcg} / \mathrm{L})$ & $7.83(1.59)$ & 7.80 & $3.45-15.2$ & $7.83(1.61)$ & 7.97 & $2.48-12.5$ & 0.67 \\
\hline $\mathrm{Hg}(\mathrm{mcg} / \mathrm{L})$ & $4.59(0.92)$ & 4.61 & $0.15-9.10$ & $4.51(0.80)$ & 4.46 & $2.72-7.90$ & 0.21 \\
\hline $\mathrm{W}(\mathrm{mcg} / \mathrm{L})$ & $0.62(0.01)$ & 0.62 & $0.28-1.11$ & $0.62(0.01)$ & 0.62 & $0.42-0.83$ & 0.67 \\
\hline \multicolumn{8}{|c|}{ Bioelements } \\
\hline $\mathrm{Mg}(\mathrm{mg} / \mathrm{L})$ & $20.6(2.05)$ & 20.6 & $10.0-26.3$ & $21.28(2.37)$ & 21.15 & $13.8-37.5$ & 0.02 \\
\hline $\mathrm{Ca}(\mathrm{mg} / \mathrm{L})$ & $95.06(6.87)$ & 95.5 & $53.5-117$ & $95.47(8.06)$ & 95.25 & $75.5-159.6$ & 0.38 \\
\hline $\mathrm{Fe}(\mathrm{mg} / \mathrm{L})$ & $1.19(0.45)$ & 1.10 & $0.28-3.40$ & $1.23(0.43)$ & 1.47 & $0.29-3.0$ & 0.35 \\
\hline $\mathrm{Zn}(\mathrm{mg} / \mathrm{L})$ & $0.90(0.14)$ & 0,90 & $0.54-1.38$ & $0.88(0.12)$ & 0.86 & $0.62-1.41$ & 0.03 \\
\hline $\mathrm{Cu}(\mathrm{mg} / \mathrm{L})$ & $1.08(0.18)$ & 1.06 & $0.46-1.89$ & $1.09(0.18)$ & 1.07 & $0.53-1.75$ & 0.60 \\
\hline $\mathrm{Cr}(\mathrm{mcg} / \mathrm{L})$ & $0.46(0.18)$ & 0.44 & $0.26-1.23$ & $0.47(0.25)$ & 0.41 & $0.01-2.74$ & 0.36 \\
\hline Mo (mcg/L) & $2.47(0.72)$ & 2.41 & $0.44-6.23$ & $2.48(0.55)$ & 2.34 & $0.10-4.53$ & 0.60 \\
\hline $\mathrm{Mn}(\mathrm{mcg} / \mathrm{L})$ & $1.90(1.17)$ & 1.67 & $0.12-10.75$ & $1.79(1.14)$ & 1.11 & $0.42-8.95$ & 0.13 \\
\hline $\mathrm{Se}(\mathrm{mcg} / \mathrm{L})$ & $106.0(13.0)$ & 106.30 & $49.7-138.1$ & $105.2(11.84)$ & 104.0 & $74.2-170.0$ & 0.21 \\
\hline
\end{tabular}

Table 3. Serum concentrations of heavy metals and bioelements in men with and without type II diabetes mellitus (TIIDM), (AM, arithmetic mean; SD, standard deviation; Med-median; $p$ : probability for trend).

\begin{tabular}{|c|c|c|c|c|c|c|c|}
\hline \multirow{2}{*}{ Metal } & \multicolumn{3}{|c|}{ TIIDM $(n=55)$} & \multicolumn{3}{|c|}{ Without TIIDM $(n=258)$} & \multirow{2}{*}{$p$} \\
\hline & AM (SD) & Med & Range & AM (SD) & Med & Range & \\
\hline \multicolumn{8}{|c|}{ Heavy Metals } \\
\hline $\mathrm{Pb}(\mathrm{mcg} / \mathrm{L})$ & $72.06(18.3)$ & 71.60 & $24.3-112.0$ & $75.05(22.2)$ & 72.0 & $26.10-161.5$ & 0.90 \\
\hline $\mathrm{Cd}(\mathrm{mcg} / \mathrm{L})$ & $1.57(0.30)$ & 1.51 & $0.59-2.05$ & $1.53(0.34)$ & 1.57 & $0.62-3.06$ & 0.46 \\
\hline As $(\mathrm{mcg} / \mathrm{L})$ & $7.82(1.35)$ & 7.65 & $5.10-10.8$ & $7.83(1.62)$ & 7.92 & $2.48-15.2$ & 0.98 \\
\hline $\mathrm{Hg}(\mathrm{mcg} / \mathrm{L})$ & $4.47(0.77)$ & 4.45 & $0.28-6.60$ & $4.57(0.88)$ & 4.53 & $0.15-9.1$ & 0.63 \\
\hline $\mathrm{W}(\mathrm{mcg} / \mathrm{L})$ & $0.61(0.1)$ & 0.61 & $0.39-0.74$ & $0.62(0.1)$ & 0.62 & $0.28-1.1$ & 0.74 \\
\hline \multicolumn{8}{|c|}{ Bioelements } \\
\hline $\mathrm{Mg}(\mathrm{mg} / \mathrm{L})$ & $19.6(2.25)$ & 19.8 & $13.8-26.3$ & $21.21(2.13)$ & 21.15 & $10.0-37.5$ & 0.0001 \\
\hline $\mathrm{Ca}(\mathrm{mg} / \mathrm{L})$ & $96.9(5.42)$ & 96.5 & $83.0-117.0$ & $94.91(9.79)$ & 95.0 & $53.5-159.6$ & 0.02 \\
\hline $\mathrm{Fe}(\mathrm{mg} / \mathrm{L})$ & $1.14(0.41)$ & 1.06 & $0.53-2.29$ & $1.22(0.44)$ & 1.45 & $0.28-3.4$ & 0.11 \\
\hline $\mathrm{Zn}(\mathrm{mg} / \mathrm{L})$ & $0.91(0.15)$ & 0.89 & $0.56-1.38$ & $0.88(0.13)$ & 0.88 & $0.54-1.41$ & 0.30 \\
\hline $\mathrm{Cu}(\mathrm{mg} / \mathrm{L})$ & $1.06(0.17)$ & 1.04 & $0.65-1.41$ & $1.09(0.18)$ & 1.06 & $0.46-1.89$ & 0.53 \\
\hline $\mathrm{Cr}(\mathrm{mcg} / \mathrm{L})$ & $0.45(0.18)$ & 0.40 & $0.13-1.13$ & $0.47(0.22)$ & 0.44 & $0.03-2.74$ & 0.74 \\
\hline Mo $(\mathrm{mcg} / \mathrm{L})$ & $2.35(0.75)$ & 2.26 & $0.11-4.53$ & $2.42(0.61)$ & 2.39 & $0.04-6.23$ & 0.87 \\
\hline $\operatorname{Mn}(\mathrm{mcg} / \mathrm{L})$ & $1.75(1.07)$ & 1.60 & $0.55-7.50$ & $1.87(1.15)$ & 1.62 & $0.12-10.75$ & 0.38 \\
\hline $\mathrm{Se}(\mathrm{mcg} / \mathrm{L})$ & $107.0(13.5)$ & 106.6 & $54.1-136.0$ & $105.3(12.16)$ & 104.5 & $49.7-170.0$ & 0.21 \\
\hline
\end{tabular}


There were no other statistically significant differences in the levels of the tested elements in men with diabetes compared to those without diabetes. Table 4 presents data on the concentrations of the tested elements in men's with overweight and obesity compared to those with normal weight. Only $\mathrm{Cr}$ and $\mathrm{Mn}$ concentrations were higher and lower, respectively, in the men with excess body weight compared to those with normal weight. The concentrations of the other elements were similar in both groups.

Table 4. Concentrations of heavy metals and bioelements in men with excess body weight and with normal body weight (AM, arithmetic mean; SD, standard deviation; Med-median; $p$ : probability for trend).

\begin{tabular}{|c|c|c|c|c|c|c|c|}
\hline \multirow{2}{*}{ Metal } & \multicolumn{3}{|c|}{ Overweight and Obesity $(\mathrm{n}=\mathbf{2 5 0})$} & \multicolumn{3}{|c|}{ Normal Body Weight $(n=61)$} & \multirow{2}{*}{$p$} \\
\hline & AM (SD) & Med & Range & AM (SD) & Med & Range & \\
\hline \multicolumn{8}{|c|}{ Heavy Metals } \\
\hline $\mathrm{Pb}(\mathrm{mcg} /)$ & $74.80(21.94)$ & 72.15 & $24.2-161,5$ & $73.30(20.0)$ & 71.81 & $30.77-123.5$ & 0.64 \\
\hline $\mathrm{Cd}(\mathrm{mcg} /)$ & $1.56(0.33)$ & 1.59 & $0.59-3.05$ & $1.48(0.32)$ & 1.53 & $0.63-2.22$ & 0.56 \\
\hline As (mcg/) & $7.79(1.58)$ & 7.72 & $3.45-15.2$ & $7.70(1.69)$ & 7.83 & $2.47-11.21$ & 0.69 \\
\hline $\mathrm{Hg}(\mathrm{mcg} /)$ & $4.56(0.87)$ & 4.52 & $0.19-9.1$ & $4.46(0.87)$ & 4.49 & $0.15-6.60$ & 0.82 \\
\hline $\mathrm{W}(\mathrm{mcg} /)$ & $0.61(0.01)$ & 0.61 & $0.28-0.83$ & $0.61(0.01)$ & 0.62 & $0.28-1.15$ & 0.22 \\
\hline \multicolumn{8}{|c|}{ Bioelements } \\
\hline $\mathrm{Mg}(\mathrm{mg} / \mathrm{L})$ & $20.7(1.81)$ & 20.8 & $15.7-26.3$ & $21.12(1.79)$ & 21.15 & $14.79-26.15$ & 0.41 \\
\hline $\mathrm{Ca}(\mathrm{mg} / \mathrm{L})$ & $96.5(5.03)$ & 95.3 & $75.5-109,5$ & $95.15(8.22)$ & 95.5 & $53.5-159.6$ & 0.60 \\
\hline $\mathrm{Fe}(\mathrm{mg} / \mathrm{L})$ & $1.17(0.45)$ & 1.09 & $0.48-3.40$ & $1.22(0.43)$ & 1.44 & $0.28-3.0$ & 0.24 \\
\hline $\mathrm{Zn}(\mathrm{mg} / \mathrm{L})$ & $0.90(0.12)$ & 0.89 & $0.56-1.31$ & $0.88(0.13)$ & 0.87 & $0.54-1.41$ & 0.14 \\
\hline $\mathrm{Cu}(\mathrm{mg} / \mathrm{L})$ & $1.09(0.15)$ & 1.07 & $0.83-1.46$ & $1.08(0.19)$ & 1.06 & $0.46-1.89$ & 0.48 \\
\hline $\mathrm{Cr}(\mathrm{mcg} / \mathrm{L})$ & $0.49(0.19)$ & 0.47 & $0.15-1.13$ & $0.45(0.22)$ & 0.41 & $0.03-2.74$ & 0.03 \\
\hline Mo $(\mathrm{mcg} / \mathrm{L})$ & $2.45(0.65)$ & 2.32 & $0.11-4.53$ & $2.43(0.64)$ & 2.34 & $0.04-6.23$ & 0.72 \\
\hline $\mathrm{Mn}(\mathrm{mcg} / \mathrm{L})$ & $2.12(1.36)$ & 1.79 & $0.60-8.95$ & $1.74(1.03)$ & 1.58 & $0.12-10.75$ & 0.005 \\
\hline $\mathrm{Se}(\mathrm{mcg} / \mathrm{L})$ & $107.4(13.2)$ & 106.0 & $54.1-138.1$ & $105.3(12.1)$ & 104.5 & $49.7-170.0$ & 0.45 \\
\hline
\end{tabular}

No relationship was found between the concentration of heavy metals and the occurrence of HA (Table 5). An almost similar pattern was observed by comparing bioelements concentrations, with the exception of $\mathrm{Mg}$. It was found that the concentration of $\mathrm{Mg}$ was significantly lower in the men with hypertension.

Significant positive correlation coefficients were found for the relations hips W-TCh $\left(\mathrm{r}_{\mathrm{s}}=0.14\right.$; $p=0.017), \mathrm{W}-\mathrm{LDL}\left(\mathrm{r}_{\mathrm{s}}=0.13 ; p=0.021\right), \mathrm{Mg}-\mathrm{TCh}\left(\mathrm{r}_{\mathrm{s}}=0.25 ; p<0.001\right), \operatorname{Mg}-\mathrm{LDL}\left(\mathrm{r}_{\mathrm{s}}=0.26\right.$; $p<0.001)$, Ca-TCh $\left(\mathrm{r}_{\mathrm{s}}=0.16 ; p=0.005\right)$, Ca-LDL $\left(\mathrm{r}_{\mathrm{s}}=0.11 ; p=0.049\right)$, Ca-insulin $\left(\mathrm{r}_{\mathrm{s}}=0.14\right.$; $p=0.023)$, Ca-HOMA-IR ( $\left.\mathrm{r}_{\mathrm{s}}=0.13 ; p=0.041\right)$, Zn-TG $\left(\mathrm{r}_{\mathrm{s}}=0.22 ; p<0.001\right)$, Zn-insulin $\left(\mathrm{r}_{\mathrm{s}}=0.18\right.$; $p=0.004), Z n-H O M A-I R\left(\mathrm{r}_{\mathrm{s}}=0.19 ; p=0.002\right)$, Cu-BP systolic $\left(\mathrm{r}_{\mathrm{s}}=0.11 ; p=0.05\right)$, Mn-BMI $\left(\mathrm{r}_{\mathrm{s}}=0.12\right.$; $p=0.029)$, Mn-AC ( $\left.\mathrm{r}_{\mathrm{s}}=0.14 ; p=0.014\right), \operatorname{Mn}-\mathrm{WHR}\left(\mathrm{r}_{\mathrm{s}}=0.17 ; p=0.002\right)$, Mn-insulin $\left(\mathrm{r}_{\mathrm{s}}=0.16\right.$; $p=0.014)$, Mn-HOMA-IR ( $\left.\mathrm{r}_{\mathrm{s}}=0.17 ; p=0.007\right)$, Se-TCh $\left(\mathrm{r}_{\mathrm{s}}=0.17 ; p=0.027\right)$, Se-LDL $\left(\mathrm{r}_{\mathrm{s}}=0.11\right.$; $p=0.004)$,Se-TG ( $\left.\mathrm{r}_{\mathrm{s}}=0.19 ; p<0.001\right)$, Se-insulin $\left(\mathrm{r}_{\mathrm{s}}=0.19 ; p=0.002\right)$, Se-HOMA-IR $\left(\mathrm{r}_{\mathrm{s}}=0.20\right.$; $p=0.002)$, Cr-TCh ( $\left.\mathrm{r}_{\mathrm{s}}=0.19 ; p<0.001\right)$, Cr-HDL ( $\left.\mathrm{r}_{\mathrm{s}}=0.14 ; p=0.012\right)$, Cr-LDL $\left(\mathrm{r}_{\mathrm{s}}=0.11 ; p=0.05\right)$, Cr-TG $\left(\mathrm{r}_{\mathrm{s}}=0.18 ; p=0.001\right)$. Significant negative correlations were found for the relations hip Cd-insulin $\left(\mathrm{r}_{\mathrm{s}}=-0.14 ; p=0.02\right), \mathrm{Hg}$-WHR $\left(\mathrm{r}_{\mathrm{s}}=-0.12 ; p=0.03\right), \mathrm{W}$-insulin $\left(\mathrm{r}_{\mathrm{s}}=-0.29 ; p<0.001\right), \mathrm{W}-\mathrm{HOMA}-\mathrm{IR}$ $\left(\mathrm{r}_{\mathrm{s}}=-0.25 ; p<0.001\right), \mathrm{Mg}-\mathrm{BMI}\left(\mathrm{r}_{\mathrm{s}}=-0.13 ; p=0.019\right), \mathrm{Mg}-\mathrm{AC}\left(\mathrm{r}_{\mathrm{s}}=-0.15 ; p=0.097\right), \mathrm{Mg}-\mathrm{WHR}$ 
$\left(\mathrm{r}_{\mathrm{s}}=-0.16 ; p=0.005\right)$, Mg-BP systolic $\left(\mathrm{r}_{\mathrm{s}}=-0.15 ; p=0.007\right)$, Mo-insulin $\left(\mathrm{r}_{\mathrm{s}}=-0.12 ; p=0.05\right)$ and Mn-HDL ( $\left.\mathrm{r}_{\mathrm{s}}=-0.16 ; p=0.048\right)$ (Table 6). A logistic regression model showed no effect of cigarette smoking on the incidence of MS in the study group $(p=0.95)$.

Table 5. Concentrations of heavy metals and bioelements in men with and without hypertension (HA) (AM, arithmetic mean; SD, standard deviation; Med-median; $p$ : probability for trend).

\begin{tabular}{|c|c|c|c|c|c|c|c|}
\hline \multirow{2}{*}{ Metal } & \multicolumn{3}{|c|}{ HA $(n=171)$} & \multicolumn{3}{|c|}{ Non-HA $(n=142)$} & \multirow{2}{*}{$p$} \\
\hline & AM (SD) & Med & Range & AM (SD) & Med & Range & \\
\hline \multicolumn{8}{|c|}{ Heavy Metals } \\
\hline $\mathrm{Pb}(\mathrm{mcg} / \mathrm{L})$ & 77.07 (21.90) & 71.11 & $26.10-161.50$ & $73.07(21.30)$ & 74.05 & $24.30-138.50$ & 0.89 \\
\hline $\mathrm{Cd}(\mathrm{mcg} / \mathrm{L})$ & $1.55(0.34)$ & 1.57 & $0.63-3.06$ & $1.54(0.32)$ & 1.53 & $0.59-2.24$ & 0.82 \\
\hline As $(\mathrm{mcg} / \mathrm{L})$ & $7.76(1.68)$ & 7.80 & $2.48-15.2$ & $7.92(1.49)$ & 7.95 & $3.83-12.5$ & 0.41 \\
\hline $\mathrm{Hg}(\mathrm{mcg} / \mathrm{L})$ & $4.59(0.89)$ & 4.53 & $0.15-9.10$ & $4.51(0.82)$ & 4.45 & $0.27-7.9$ & 0.25 \\
\hline $\mathrm{W}(\mathrm{mcg} / \mathrm{L})$ & $0.62(0.01)$ & 0.61 & $0.15-0.91$ & $0.62(0.01)$ & 0.63 & $0.39-0.83$ & 0.11 \\
\hline \multicolumn{8}{|c|}{ Bioelements } \\
\hline $\mathrm{Mg}(\mathrm{mg} / \mathrm{L})$ & $20.58(2.59)$ & 20.5 & $10.0-37.5$ & $21.36(1.61)$ & 21.3 & $16.6-26.3$ & 0.00012 \\
\hline $\mathrm{Ca}(\mathrm{mg} / \mathrm{L})$ & $95.39(8.93)$ & 95.0 & $53.5-159.6$ & $95.10(5.19)$ & 95.5 & $77.0-109.5$ & 0.72 \\
\hline $\mathrm{Fe}(\mathrm{mg} / \mathrm{L})$ & $1.21(0.46)$ & 1.07 & $0.29-3.40$ & $1.21(0.40)$ & 1.25 & $0.28-2.38$ & 0.79 \\
\hline $\mathrm{Zn}(\mathrm{mg} / \mathrm{L})$ & $0.88(0.14)$ & 0.88 & $0.54-1.41$ & $0.89(0.12)$ & 0.88 & $0.64-1.29$ & 0.20 \\
\hline $\mathrm{Cu}(\mathrm{mg} / \mathrm{L})$ & $1.08(0.19)$ & 1.06 & $0.46-1.89$ & $1.07(0.16)$ & 1.06 & $0.53-1.46$ & 0.77 \\
\hline $\mathrm{Cr}(\mathrm{mcg} / \mathrm{L})$ & $0.44(0.18)$ & 0.42 & $0.26-3.17$ & $0.49(0.25)$ & 0.44 & $0.02-2.74$ & 0.09 \\
\hline Mo $(\mathrm{mcg} / \mathrm{L})$ & $2.39(0.64)$ & 2.32 & $0.44-4.39$ & $2.50(0.63)$ & 2.43 & $1.35-6.23$ & 0.16 \\
\hline $\operatorname{Mn}(\mathrm{mcg} / \mathrm{L})$ & $1.86(1.12)$ & 1.62 & $0.12-10.75$ & $1.83(1.06)$ & 1.63 & $0.42-8.95$ & 0.85 \\
\hline $\mathrm{Se}(\mathrm{mcg} / \mathrm{L})$ & $105.6(13.9)$ & 104.5 & $49.7-170.0$ & $105.7(10.2)$ & 105.0 & $74.2-136.0$ & 0.86 \\
\hline
\end{tabular}

\section{Discussion}

\subsection{Heavy Metals}

In this study we found no statistically significant differences in the concentrations of heavy metals $(\mathrm{Pb}, \mathrm{Cd}, \mathrm{Hg}$, As and $\mathrm{W}$ ) between the men with MS (as well as those with the components of the MS, such as hypertension, obesity and diabetes) and healthy participants. This may be due to cut between having MS and not depends on levels of a number of markers and is not a uniform cut off, so risk prediction is not very accurate [38]. However, the correlation coefficients of all participants together was most negative $(r=-0.29$ and $-0.25, p<0.001)$ for $\mathrm{W}-$ Insulin and W-Homa-IR of all analyses made in this study, and there was also a week correlation with $\mathrm{Cd}$ and insulin. Whether this was a toxic effect of $\mathrm{W}$ and $\mathrm{Cd}$ on pancreatic cells or some other is not clear. Decreased pancreatic insulin reserve and action could precipitate hypo-insulinaemic diabetes, and late stage TIIDM. The positive correlation which we observed between W and TCh and LDL levels further suggests that a higher W may be atherogenic, as confirmed by epidemiological studies. This can be explained by the fact that in the etiology of atherosclerosis an important role is played by oxidative stress and inflammation, and $\mathrm{W}$ is pro-inflammatory and involved in the production of free radicals (as the component of oxidoreducates). Some results report that environmental exposure to $\mathrm{W}$ intoxication may contribute to the development 
of cardiovascular and cerebrovascular diseases [39,40]. West Pomerania is an agricultural and industrial region. The main branch of the economy is agriculture and the food industry. Other important industries are: timber, metallurgy, chemicals, shipbuilding, and the production of electricity. Environmental conditions in the region have been improving for many years. Emissions of pollutants into the air from point sources (industry, energy) have tended to decline. This is related to ecological investment, mainly in the energy sector (report on the state of the city of Szczecin, 2012). At the same time a large part of the region is legally protected under the Wildlife Protection Act (Dz. U. 2004, No. 92, item. 880), and some areas are part of the European Ecological Network Natura 2000-Special Protection Areas-Wkrzańska refuge, Świdwie Lake, Goleniów Forest and Skoszew Grasslands (Dz. U. 2008, No. 198, item. 1226); those areas at least partially overlap with the area of research [41]. Thus these older men may be showing evidence of past accumulated exposure to heavy metals from the above industry with inadequate pollution management or perhaps there is still industrial residue in the areas under horticulture.

\subsection{Bioelements}

In this study, Mg levels in participants with MS were significantly lower than in those without MS, which is consistent with the research of Guerrero-Romero et al. [42,43]. We also found that our participants from north-western Poland with diabetes and hypertension had significantly lower $\mathrm{Mg}$ concentration compared to those without these conditions. The results of this study regarding participants with diabetes are consistent with the results of other authors [42,44]. Sun et al. [31] indicate a reduced $\mathrm{Mg}$ concentration in people with MS and type 2 TIIDM, and a statistically significant negative correlation between $\mathrm{Mg}$ concentration and the coefficient of insulin resistance [31]. These authors also report significantly lower Mg concentration in people with overweight and obesity. In our study this relationship was not observed. Choi et al. [45] demonstrated that participants with MS had a lower intake of $\mathrm{Mg}$ than the control group. Our results show that the greater the abdominal circumference, BMI, WHR and BP, the lower Mg concentration in the serum, which may result from a high-fat and high-carbohydrate diet.. Likewise, Sun et al. [31] indicate a statistically significant negative correlation between $\mathrm{Mg}$ concentration and both BMI and WHR in the participants. On the other hand, our study found positive correlations between the concentrations of $\mathrm{Mg}$ to $\mathrm{TCh}$ or LDL, which is consistent with studies of Nasri et al. [46]. The dependencies and correlations presented between $\mathrm{Mg}$ concentration and the analyzed parameters may suggest that $\mathrm{Mg}$ does not protect against disorders of lipid metabolism but may have a beneficial effect on blood pressure, carbohydrate metabolism, and reduce the risk of abdominal obesity. In contrast, Sun et al. [31] present no relationship between $\mathrm{Mg}$ concentration and lipid parameters in a study conducted with both men and women. Mak et al. [47] report that $\mathrm{Mg}$ supplementation improves the lipid profile and thus helps to reduce the risk of cardiovascular disease.

In this study we found that Ca may be associated with impaired lipid and carbohydrate metabolism, as evidenced by the positive correlations between the concentrations of this element and the concentrations of TCh, LDL, insulin and HOMA-IR. Furthermore, statistically significantly higher Ca concentration were found in the participants with diabetes. The results by Sun et al. [31] on lipid metabolism are similar to those presented here, but the authors found no correlation between $\mathrm{Mg}$ 
concentration and the parameters of carbohydrate metabolism. Likewise, Park et al. [48] report a statistically significant correlation between $\mathrm{Ca}$ concentration and the occurrence of MS in Korean men aged from 30 to 60 years.

The men with MS from the study group indicated a significantly higher $\mathrm{Zn}$ concentration than those without MS. None of the study participants had symptoms of $\mathrm{Zn}$ deficiency. Due to the positive correlation between $\mathrm{Zn}$ and insulin concentrations as well as HOMA-IR in the examined participants without diabetes, lower $\mathrm{Zn}$ levels may relate to disturbance of carbohydrate metabolism. The role of $\mathrm{Zn}$ in carbohydrate metabolism is complex. Zinc plays an important role in synthesis, storage and release of insulin [49]. This element affects the functioning of the beta cells in the islets of Langerhans. Animal research shows that $\mathrm{Zn}$ administered in small doses protects against type 2 diabetes but a high concentration of the element is toxic to the beta cells in the islets of Langerhans [50]. In this study we also observed a positive correlation between $\mathrm{Zn}$ and TG concentrations., similar to Seo et al. [51] and Ghasemi et al. [52]. Research by Seo et al. [51] suggests that high serum zinc levels might be associated with metabolic risk factors (TG and waist circumference) in men, but not in women. Obeid et al. [30] report no statistically significant correlation between the concentration of $\mathrm{Zn}$ and MS with its individual components in adults from Lebanon aged 18-65 years. Ahn et al. [53] also find no connection between the occurrence of MS and $\mathrm{Zn}$ concentration and indicate a negative correlation between the concentration of this element and HOMA-IR.

With respect to $\mathrm{Cu}$ we found that the men in our study indicated a positive correlation on the verge of statistical significance with and systolic and diastolic BP. We observed no correlation between the concentration of this element and other parameters of MS. The findings of other authors suggest that $\mathrm{Cu}$ concentration in patients with $\mathrm{HA}$ is significantly higher [54]. Afridi et al. [55] show that deficiency of $\mathrm{Cu}$ is synergistically associated with other risk factors for high blood pressure. Carpenter et al. [56] on the basis of results of other authors on the role of $\mathrm{Cu}$ in $\mathrm{HA}$, argue it is difficult to draw definite conclusions due to the lack of homogeneity of the study groups.

Drawing on the findings of other authors, Onapkoya et al. [57] report that Cr supplementation causes weight loss, but the effect is small and of uncertain clinical significance. Indeed, our study revealed that $\mathrm{Cr}$ concentration in men with obesity and overweight was significantly higher and a positive correlation between $\mathrm{Cr}$ concentration and BMI was of borderline statistical significance $(p=0.057)$. Similarly, in women from southern Poland a statistically significant positive correlation existed between $\mathrm{Cr}$ concentration and BMI [58]. In contrast, Yerlikaya et al. [59] report no significant differences in $\mathrm{Cr}$ concentration in obese women compared to the control group. In the study presented here, we found an association between $\mathrm{Cr}$ concentration and lipid metabolism parameters, but there was no such relationship for carbohydrate metabolism. Likewise, Sun et al. [31] indicate a relationship between the concentrations of $\mathrm{Cr}$ and lipid components with the exception of HDL. These researchers also show statistically significant positive correlations between the concentrations of $\mathrm{Cr}$ to insulin and HOMA-IR. Kim et al. [60] indicate that in men with visceral obesity $\mathrm{Cr}$ level in hair is positively correlated with insulin resistance, and Chung et al. [61] report lower $\mathrm{Cr}$ level in the hair of men with MS. 
Table 6. Spearman correlation coefficients between element levels and metabolic features (BMI, Body Mass index; AB, abdominal circumference; WHR, waist-to-hip ratio; BP, blood pressure; TCh, total cholesterol; HDL, high-density lipoprotein; LDL, low-density lipoprotein; TG, triglyceride; HOMA-IR, Homeostasis Model Assessment_-Insulin resistance).

\begin{tabular}{|c|c|c|c|c|c|c|c|c|c|c|c|c|c|c|}
\hline $\begin{array}{c}\text { Metabolic } \\
\text { Features }\end{array}$ & $\mathbf{P b}$ & Cd & Hg & As & $\mathbf{W}$ & Mg & $\mathbf{C a}$ & $\mathbf{F e}$ & $\mathbf{Z n}$ & $\mathbf{C u}$ & Mo & Mn & Se & $\mathbf{C r}$ \\
\hline BMI & 0.02 & 0.06 & 0.57 & -0.03 & 0.01 & $-0.13 *$ & 0.01 & -0.09 & 0.08 & 0.02 & -0.019 & $0.12 *$ & 0.03 & 0.12 \\
\hline $\mathrm{AB}$ & 0.04 & 0.06 & 0.01 & -0.03 & -0.04 & $-0.15 *$ & 0.03 & -0.08 & 0.06 & 0.05 & 0.04 & $0.14 *$ & 0.07 & 0.11 \\
\hline WHR & -0.07 & -0.07 & $-0.12 *$ & -0.08 & -0.14 * & $-0.16 *$ & 0.008 & -0.05 & 0.003 & 0.07 & 0.004 & $0.17 *$ & 0.04 & 0.04 \\
\hline BP systolic & 0.06 & 0.04 & -0.02 & 0.07 & -0.06 & $-0.15 *$ & -0.0007 & 0.04 & 0.001 & $0.11^{*}$ & 0.06 & -0.019 & 0.07 & -0.004 \\
\hline BP diastolic & 0.04 & -0.02 & -0.02 & 0.04 & -0.11 & -0.0004 & 0.04 & 0.04 & 0.08 & 0.10 & 0.1 & 0.03 & 0.11 & 0.02 \\
\hline $\mathrm{TCh}$ & -0.08 & -0.001 & -0.04 & -0.04 & $0.14 *$ & $0.25 *$ & $0.16^{*}$ & -0.02 & 0.09 & 0.04 & 0.03 & 0.06 & $0.17 *$ & $0.19 *$ \\
\hline HDL & -0.07 & -0.03 & -0.09 & 0.04 & 0.9 & 0.009 & 0.02 & 0.09 & -0.07 & -0.05 & 0.05 & $-0.16 *$ & -0.05 & $0.14 *$ \\
\hline LDL & -0.03 & 0.04 & -0.02 & -0.03 & $0.13 *$ & $0.26 *$ & $0.11 *$ & -0.04 & 0.03 & 0.04 & -0.007 & 0.09 & $0.11 *$ & $0.11 *$ \\
\hline $\mathrm{TG}$ & -0.07 & -0.07 & 0.04 & -0.04 & -0.05 & -0.06 & 0.098 & -0.05 & 0.22 * & 0.05 & 0.03 & 0.02 & 0.19 * & $0.18 *$ \\
\hline Insulin & -0.06 & $-0.14 *$ & 0.01 & -0.06 & $-0.29 *$ & -0.019 & $0.14 *$ & -0.07 & $0.18 *$ & 0.06 & $-0.12 *$ & $0.16 *$ & $0.19 *$ & -0.09 \\
\hline HOMA-IR & -0.07 & -0.11 & 0.004 & -0.09 & $-0.25 *$ & -0.056 & $0.13 *$ & -0.02 & 0.19 * & 0.04 & -0.96 & $0.17 *$ & $0.20 *$ & -0.08 \\
\hline FPG & -0.05 & 0.02 & 0.04 & -0.05 & 0.06 & -0.11 & -0.4 & 0.09 & 0.04 & -0.08 & 0.05 & 0.05 & -0.005 & -0.05 \\
\hline
\end{tabular}


We found a relationship between Se concentration and lipid metabolism (with the exception of HDL) and carbohydrate parameters (insulin and HOMA-IR), which suggests that higher concentrations of this element may contribute to metabolic disorders. Similar results were obtained by Kim et al. [60] and Sun et al. [31]. On the other hand, Aranud et al. [62] report that in women with MS but without TIIDM Se concentration is higher, while in men no such correlation is observed. Furthermore, Obeid et al. [30] indicate positive correlations between Se concentration and the values of all measured parameters characteristic of MS. The results of this study and other authors suggest that Se may contribute to the development of MS.

In the present study, we found a statistically significant higher Mn concentration in the obese men and observed a positive correlation between Mn concentration and the anthropometry and parameters of carbohydrate metabolism (insulin, HOMA-IR), and a negative correlation between the concentrations of Mn and HDL. In contrast, Al-Sabaawy [63] reported that Mn concentration in both the men with dyslipidemia and the control group were similar. Likewise, no statistically significant correlation between the concentration of $\mathrm{Mn}$ and lipid parameters was observed by Sun et al. [31]. Those researchers also pointed out a statistically significant negative correlation between $\mathrm{Mn}$ concentration and carbohydrate metabolism. Forte et al. [64] showed that Mn concentration in people with diabetes mellitus type 1 and 2 was lower than in healthy participants. Koh et al. [65] suggest that Mn may play a protective role in diabetes. On the other hand, no such relationship was present in seniors from the Czech Republic [66].

In available literature, there is little data on the relationship between Mo and metabolic disorders. Flores et al. [67] show that antagonistic interactions between $\mathrm{Mo}$ and $\mathrm{Cu}$ may increase the progression of diabetic complications. In the present study, as well as in the research of Sun et al. [31], there was a positive correlation between the concentrations of Mo and insulin. Moreover, Sun et al. [31] indicate a statistically significant positive correlation between Mo concentration and HOMA-IR. The results of our and other authors' studies may indicate a role of Mo in the formation of carbohydrate metabolism disorders.

The results of this study and those of other authors on the relationship between bioelements and MS with its components and other metabolic parameters are inconclusive. Therefore, mineral supplementation cannot be recommended as a means of prevention of metabolic disorders. Also Czernichow et al. [68] question the benefits of supplementation with minerals, including antioxidants, despite the lack of side effects. For that reason, comprehensive total diet analyses, including plant and animal based foods, should be run on the population Additional and methodologically comprehensive population-based (modeling) studies should be carried out to further determine the significance of macro- and microelements for human health.

\section{Conclusions}

In the studied men aged 50-75 years who had not been knowingly exposed to heavy metals in their work or living environment, the data showed that higher $\mathrm{W}$ concentrations may be a contributing factor to dyslipidaemia. Among the macroelements, $\mathrm{Mg}$ seemed to have a protective role in the occurrence of metabolic disorders, especially through beneficial effects on carbohydrate metabolism, blood pressure and anthropometric parameters. Higher concentrations of $\mathrm{Ca}$ in diabetics and positive 
correlations with HOMA-IR and insulin levels may indicate a detrimental effect of this mineral on carbohydrate metabolism. Microelements such as $\mathrm{Mn}, \mathrm{Cr}$ and Se may contribute to the incidence of metabolic disorders. However, it was not possible to unambiguously assess their relevance to the formation, occurrence and severity of metabolic disorders in men.

\section{Acknowlegments}

The study was financed as research project No. FSN (stimulation fund research) WNoZ 321-10/13 by Pomeranian Medical University in Szczecin.

\section{Author Contributions}

Iwona Rotter designed study and collected data; Iwona Rotter, Danuta Kosik-Bogacka, Barbara Dołęgowska, Anna Lubkowska, and Maria Laszczyńska conducted data analysis; Krzysztof Safranow conducted statistical analysis; Iwona Rotter and Danuta Kosik-Bogacka drafted the manuscript; all authors have red and approved the final version submitted for publication.

$\begin{array}{ll}\text { Abbreviations } \\ \text { MS } & \text { Metabolic syndrome } \\ \text { TIIDM } & \text { Type II diabetes mellitus } \\ \text { BMI } & \text { Body mass index } \\ \text { AC } & \text { Abdominal circumference } \\ \text { WHR } & \text { Waist-to-hip ratio } \\ \text { TCh } & \text { Total cholesterol } \\ \text { LDL } & \text { Low-density lipoprotein } \\ \mathrm{HDL} & \text { High-density lipoprotein } \\ \text { TG } & \text { Triglyceride } \\ \text { FPG } & \text { Fasting plasma glucose } \\ \mathrm{HOMA}-\mathrm{IR} & \text { Homeostasis Model Assessment - Insulin resistance } \\ \mathrm{IR} & \text { Insulin resistance } \\ \mathrm{BP} & \text { Blood pressure } \\ \mathrm{HA} & \text { Hypertension } \\ \mathrm{Pb} & \text { Lead } \\ \mathrm{Hg} & \text { Mercury } \\ \mathrm{As} & \text { Arsenic } \\ \mathrm{Cd} & \text { Cadmium } \\ \mathrm{W} & \text { Tungsten } \\ \mathrm{Mg} & \text { Magnesium } \\ \mathrm{Fe} & \text { Iron } \\ \mathrm{Ca} & \text { Calcium } \\ \mathrm{Zn} & \text { Zinc } \\ \mathrm{Cu} & \text { Copper } \\ \mathrm{Se} & \text { Selenium } \\ \end{array}$


Mn Manganese

$\mathrm{Cr} \quad$ Chromium

Mo Molybdenum

\section{Conflicts of Interest}

The authors declare no conflict of interest.

\section{References}

1. Wyrzykowski, B.; Zdrojewski, T.; Bandosz, P. Metabolic syndrome in Poland. Kardiol. Pol. 2005, 62, 30-35.

2. Stern, M.P.; Williams, K.; Gonzales-Villalpando, C.; Hunt, K.J.; Haffner, S.M. Does the metabolic syndrome improve identification of individuals at risk of type 2 diabetes and/or cardiovascular disease? Diabetes Care 2004, 27, 2676-2681.

3. Zdrojewski, T.; Bandosz, P.; Szpakowski, P.; Konarski, R.; Manikowski, A.; Wolkiewicz, E.; Jakubowski, Z.; Lysiak-Szydlowska, W.; Bautembach, S.; Wyrzykowski, B. The prevalence of major risk factors of diseases of the cardiovascular system in Poland. Results of the study NATPOL PLUS. Kardiol. Pol. 2004, 61, 1-26.

4. Navas-Acien, A.; Silbergeld, E.K.; Pastor-Barriuso, R.; Guallar, E. Arsenic exposure and prevalence of type 2 diabetes in US adults. J. Amer. Med. Assn. 2008, 300, 814-822.

5. Nash, D.; Magder, L.; Lustberg, M.; Sherwin, R.W.; Rubin, R.J.; Kaufmann, R.B.; Silbergeld, E.K. Blood lead, blood pressure, and hypertension in perimenopausal and postmenopausal women. J. Amer. Med. Assn. 2003, 289, 1523-1532.

6. Rhee, S.Y.; Hwang, Y.C.; Woo, J.T.; Sinn, D.H.; Chin, S.O.; Chon, S.; Kim, Y.S. Blood lead is significantly associated with metabolic syndrome in Korean adults: An analysis based on the Korea National Health and Nutrition Examination Survey (KNHANES) 2008. Cardiovasc. Diabetol. 2013, doi:10.1186/1475-2840-12-9.

7. Lee, B.K.; Kim, Y. Blood cadmium, mercury, and lead and metabolic syndrome in South Korea: 2005-2010 Korean National Health and Nutrition Examination Survey. Amer. J. Ind. Med. 2013, $56,682-692$.

8. Byrne, J.V.; Hope, J.K.; Hubbard, N.; Morris, J.H. The nature of thrombosis induced by platinum and tungsten coils in saccular aneurysms. Amer. J. Neuroradiol. 1997, 18, 29-33.

9. Johnson, J.L.; Waud, W.R.; Cohen, H.J.; Rajagopalan, K.V. Molecular basis of the biological function of molybdenum. Molybdenum-free xanthine oxidase from livers of tungstentreated rats. J. Biol. Chem. 1974, 249, 5056-5061.

10. Nell, J.A.; Annison, E.F.; Balnave, D. The influence of tungsten on the molybdenum status of poultry. Brit. Poult. Sci. 1980, 21, 193-202.

11. Claret, M.; Corominola, M.; Saura, J.; Barcelo-Batllori, S.; Guinovart, J.J.; Gomis, R. Tungstate decreases weight gain and adiposity in obese rats through increased thermogenesis and lipid oxidation. Endocrinology 2005, 146, 4362-4369. 
12. Ballester, J.; Munoz, M.C.; Domínguez, J.; Palomo, M.J.; Rivera, M.; Rigau, T.; Guinovart, J.J.; Rodríguez-Gil, J.E. Tungstate administration improves the sexual and reproductive function in female rats with streptozotocin-induced diabetes. Hum. Reprod. 2007, 22, 2128-2135.

13. Guerrero-Romero, F.; Rodriguez-Moran, M. Low serum magnesium levels and metabolic syndrome. Acta. Diabetol. 2002, 39, 209-213.

14. Song, Y.; Sesso, H.D.; Manson, J.E.; Cook, N.R.; Buring, J.E.; Liu, S. Dietary magnesium intake and risk of incident hypertension among middle-aged and older US women in a 10-year follow-up study. Amer. J. Cardiol. 2006, 98, 1616-1621.

15. Volpe, S.L. Magnesium, the metabolic syndrome, insulin resistance, and type 2 diabetes mellitus. Crit. Rev. Food Sci. Nutr. 2008, 48, 293-300.

16. Cosaro, E.; Bonafini, S.; Montagnana, M.; Danese, E.; Trettene, M.S.; Minuz, P.; Delva, P.; Fava, C. Effects of magnesium supplements on blood pressure, endothelial function and metabolic parameters in healthy young men with a family history of metabolic syndrome. Nutr. Metab. Cardiovasc. Dis. 2014, 24, 1213-1220.

17. Guerrero-Romero, F.; Rodriguez-Moran, M. Oral magnesium supplementation: An adjuvant alternative to facing the worldwide challenge of type 2 diabetes? Medigraphic 2014, 82, 282-289.

18. De Souza E Silva, M.L.L.; Cruz, T.; Rodrigues, L.E.; Ladeia, A.M.; Bomfim, O.; Olivieri, L.; Melo, J.; Correia, R.; Porto, M.; Cedro, A. Magnesium replacement does not improve insulin resistance in patients with metabolic syndrome: A 12-week randomized double-blind study. J. Clin. Med. Res. 2014, 6, 456-462.

19. Jehn, M.; Clark, J.M.; Guallar, E. Serum ferritin and risk of the metabolic syndrome in U.S. adults. Diabetes Care 2004, 27, 2422-2428.

20. Bozzini, C.; Girelli, D.; Olivieri, O.; Martinelli, N.; Bassi, A.; DeMatteis, G.; Tenuti, I.; Lotto, V.; Friso, S.; Pizzolo, F.; Corrocher, R. Prevalence of body iron excess in the metabolic syndrome. Diabetes Care 2005, 28, 2061-2063.

21. Choi, K.M.; Lee, K.W.; Kim, H.Y.; Seo, J.A.; Kim, S.G.; Kim, N.H.; Choi, D.S.; Baik, S.H. Association among serum ferritin, alanine aminotransferase levels, and metabolic syndrome in Korean postmenopausal women. Metabolism 2005, 54, 1510-1514.

22. Gonzalez, A.S.; Guerrero, D.B.; Soto, M.B.; Diaz, S.P.; Martinez-Olmos, M.; Vidal, O. Metabolic syndrome, insulin resistance and the inflammation markers C-reactive protein and ferritin. Eur. J. Clin. Nutr. 2006, 60, 802-809.

23. Sun, L.; Franco, O.H.; Hu, F.B.; Cai, L.; Yu, Z.; Li, H.; Ye, X.; Qi, Q.; Wang, J.; Pan, A.; Liu, Y.; Lin, X. Ferritin concentrations, metabolic syndrome, and type 2 diabetes in middle-aged and elderly chinese. J. Clin. Endocrinol. MeTable 2008, 93, 4690-4696.

24. Naka, T.; Kaneto, H.; Katakami, N.; Matsuoka, T.; Harada, A.; Yamasaki, Y.; Matsuhisa, M.; Shimomura, I. Association of serum copper levels and glycemic control in patients with type 2 diabetes. Endocr. J. 2013, 60, 393-396.

25. Ferdousi, S.; Mia, A.R. Serum levels of copper and zinc in newly diagnosed type-2 diabetic subjects. Mymensingh. Med. J. 2012; 21, 475-478.

26. Xu, J.; Zhou, Q.; Liu, G.; Tan, Y.; Cai, L. Analysis of serum and urinal copper and zinc in Chinese northeast population with the prediabetes or diabetes with and without complications. Oxid. Med. Cell. Longev. 2013, doi:10.1155/2013/635214. 
27. Miao, X.; Sun, W.; Fu, Y.; Miao, L.; Cai, L. Zinc homeostasis in the metabolic syndrome and diabetes. Front. Med. 2013, 7, 31-52.

28. Pallauf, K.; Rivas-Gonzalo, J.C.; del Castillo, M.D.; Cano, M.P.; de Pascual-Teresa, S. Characterization of the antioxidant composition of strawberry tree (Arbutus unedo L.) fruits. J. Food Compos. Anal. 2008, 21, 273-281.

29. Siddiqui, K.; Bawazeer, N.; Joy, S.S. Variation in macro and trace elements in progression of type 2 diabetes. Scientific World Journal 2014, 2014, 461-591.

30. Obeid, O.; Elfakhani, M.; Hlais, S.; Iskandar, M.; Batal, M.; Mouneimne, Y.; Adra, N.; Hwalla, N. Plasma copper, zinc, and selenium levels and correlates with metabolic syndrome components of lebanese adults. Biol. Trace Elem. Res. 2008, 123, 58-65.

31. Sun, L.; Yu, Y.; Huang, T.; An, P.; Yu, D.; Yu, Z.; Li, H.; Sheng, H.; Cai, L.; Xue, J.; Jing, M.; Li, Y.; Lin, X.; Wang, F. Associations between ionomic profile and metabolic abnormalities in human population. PLoS One 2012, doi:10.1371/journal .pone. 0038845.

32. Korc, M. Manganese action on pancreatic protein synthesis in normal and diabetic rats. Amer. $J$. Physiol. 1983, 245, 628-634.

33. Pechova, A.; Pavlata, L. Chromium as an essential nutrient: A review. Vet. Med. 2007, 52, 1-18.

34. Hopps, E.; Noto, D.; Caimi, G.; Averna, M.R. A novel comoponent of the metabolic syndrome: The oxidative stress. Nutr. Metab. Cardiovasc. Dis. 2010, 20, 72-77.

35. Cooper, G.J. Selective divalent copper chelation for the treatment of diabetes mellitus. Curr. Med. Chem. 2012, 19, 2828-2860.

36. Marseglia, L.; Manti, S.; d'Angelo, G.; Nicotera, A.; Parisi, E.; Di Rosa, G.; Gitto, E.; Arrigo, T. Oxidative stress in obesity: A critical component in human diseases. Int. J. Mol. Sci. 2014, 16, $378-400$.

37. Alberti, K.G.; Zimmet, P.; Shaw, J. The metabolic syndrome-a new worldwide definition. Lancet 2005, 366, 1059-1062.

38. Strazzullo, P.; Barbato, A.; Siani, A.; Cappuccio, F.P.; Versiero, M.; Schiattarella, P.; Russo, O.; Avallone, S.; della Valle, E.; Farinaro, E. Diagnostic criteria for metabolic syndrome: A comparative analysis in an unselected sample of adult male population. Metabolism 2008, 57, 355-361.

39. Agarwal, S.; Zaman, T.; Tuzcu, E.M.; Kapadia, S.R. Heavy metals and cardiovascular disease: Results from the National Health and Nutrition Examination Survey (NHANES) 1999-2006. Angiology. 2011, 62, 422-429.

40. Tyrrell, J.; Galloway, T.S.; Abo-Zaid, G.; Melzer, D.; Depledge, M.H.; Osborne, N.J. High urinary tungsten concentration is associated with stroke in the National Health and Nutrition Examination Survey 1999-2010. PLoS One 2013, doi: 10.1371/journal.pone.0077546.

41. Report on the state of Szczecin city, 2012. Szczecin. Available online: http://bip.um.szczecin.pl/UMSzczecinFiles/file/Raport_o_stanie_miasta_SZCZECIN_2013_pdf (accessed on 3 April 2015).

42. Guerrero-Romero, F.; Rascon-Pacheco, R.A.; Rodriguez-Moran, M.; de la Pena, J.E.; Wacher, N. Hypomagnesaemia and risk for metabolic glucose disorders: A 10-year follow-up study. Eur. J. Clin. Invest. 2008, 38, 389-396. 
43. Guerrero-Romero, F.; Rodriguez-Moran, M. Serum magnesium in the metabolically-obese normal-weight and healthy-obese subjects. Eur. J. Intern. Med. 2013, 24, 639-643.

44. Corica, F.; Corsonello, A.; Ientile, R.; Cacinotta, D.; di Benedetto, A.; Perticone, F.; Dominguez, L.J.; Barbagallo, M. Serum ionized magnesium levels in relation to metabolic syndrome in type 2 diabetic patients. J. Amer. Coll. Nutr. 2006, 25, 210-215.

45. Choi, M.K.; Bae, Y.J. Relationship between dietary magnesium, manganese, and copper and metabolic syndrome risk in Korean adults: the Korea National Health and Nutrition Examination Survey (2007-2008). Biol. Trace Elem. Res. 2013, 156, 56-66.

46. Nasri, H.; Baradaran, H.R. Lipid in association with serum magnesium in diabetes mellitus patients. Bratisl. Lek. Listy. 2008, 109, 302-306.

47. Mak, I.T.; Kramer, J.H.; Chen, X.; Chmielinska, J.J.; Spurney, C.F.; Weglicki, W.B. $\mathrm{Mg}$ supplementation attenuates ritonavir-induced hyperlipidemia, oxidative stress, and cardiac dysfunction in rats. Amer. J Physiol. 2013, 305, 1102-1111.

48. Park, S.H.; Kim, S.K.; Bae, Y.J. Relationship between serum calcium and magnesium concentrations and metabolic syndrome diagnostic components in middle-aged Korean men. Biol. Trace Elem. Res. 2012, 146, 35-41.

49. Meyer, J.A.; Spence, D.M. A perspective on the role of metals in diabetes: Past findings and possible future directions. Metallomics. 2009, 1, 32-41.

50. Pushparani, D.S.; Anandan, S.N.; Theagarayan, P. Serum zinc and magnesium concentrations in type 2 diabetes mellitus with periodontitis. J. Indian Soc. Periodontol. 2014, 18, 187-193.

51. Seo, J.A.; Song, S.W.; Han, K.; Lee, K.J.; Kim, H.N. The associations between serum zinc levels and metabolic syndrome in the Korean population: Findings from the 2010 Korean National Health and Nutrition Examination Survey. PLoS One 2014, doi:10.1371/journal.pone.0105990.

52. Ghasemi, A.; Zahediasl, S.; Hosseini-Esfahani, F.; Azizi, F. Gender differences in the relationship between serum zinc concentration and metabolic syndrome. Ann. Hum. Biol. 2014, 41, 436-442.

53. Ahn, B.I.; Kim, M.J.; Koo, H.S.; Seo, N.; Joo, N.S.; Kim, Y.S. Serum zinc concentration is inversely associated with insulin resistance but not related with metabolic syndrome in nondiabetic Korean adults. Biol. Trace Elem. Res. 2014, 160, 169-175.

54. Ghayour-Mobarhan, M.; Shapouri-Moghaddam, A.; Azimi-Nezhad, M.; Esmaeili, H.; Parizadeh, S.M.; Safarian, M.; Kazemi-Bajestani, S.M.; Khodaei, G.H.; Hosseini, S.J.; Parizadeh, S.M.; Ferns, G.A. The relationship between established coronary risk factors and serum copper and zinc concentrations in a large Persian Cohort. J. Trace Elem. Med. Biol. 2009, 23, 167-175.

55. Afridi, H.I.; Kazi, T.G.; Kazi, N.; Talpur, F.N.; Naeemullah Arain, S.S.; Brahman, K.D.; Wadhwa, S.K.; Shah, F. Distribution of copper, iron, and zinc in biological samples of Pakistani hypertensive patients and referent subjects of different age groups. Clin. Lab. 2013, 59, 959-967.

56. Carpenter, W.E.; Lam, D.; Toney, G.M.; Weintraub, N.L.; Qin, Z. Zinc, copper, and blood pressure: Human population studies. Med. Sci. Monit. 2013, 19, 1-8.

57. Onakpoya, I.; Posadzki, P.; Ernst, E. Chromium supplementation in overweight and obesity: A systematic review and meta-analysis of randomized clinical trials. Obes. Rev. 2013, 14, 496-507.

58. Wiechula, D.; Loska, K.; Ungier, D.; Fischer, A. Chromium, zinc and magnesium concentrations in the pubic hair of obese and overweight women. Biol. Trace Elem. Res. 2012, 148, 18-24. 
59. Yerlikaya, F.H.; Toker, A.; Arıbas, A. Serum trace elements in obese women with or without diabetes. Indian J. Med. Res. 2013, 137, 339-345.

60. Kim, H.N.; Song, S.W. Concentrations of chromium, selenium, and copper in the hair of viscerally obese adults are associated with insulin resistance. Biol. Trace Elem. Res. 2014, 158, $152-157$.

61. Chung, J.H.; Yum, K.S. Correlation of hair mineral concentrations with insulin resistance in Korean males. Biol. Trace Elem. Res. 2012, 150, 26-30.

62. Arnaud, J.; de Lorgeril, M.; Akbaraly, T.; Salen, P.; Arnout, J.; Cappuccio, F.P.; van Dongen, M.C.; Donati, M.B.; Krogh, V.; Siani, A.; Iacoviello, L.; European Collaborative Group of the IMMIDIET Project. Gender differences in copper, zinc and selenium status in diabetic-free metabolic syndrome European population-The IMMIDIET study. Nutr. Metab. Cardiovasc. Dis. 2012, 22, 517-524.

63. Al-Sabaawy, O.M. The relationship between serum lipid profile and selected trace elements for adult men in mosul city. Oman Med. J. 2012, 27, 300-303.

64. Forte, G.; Bocca, B.; Peruzzu, A.; Tolu, F.; Asara, Y.; Farace, C.; Oggiano, R.; Madeddu, R. Blood metals concentration in type 1 and type 2 diabetics. Biol. Trace Elem. Res. 2013, 156, 79-90.

65. Koh, E.S.; Kim, S.J.; Yoon, H.E.; Chung, J.H.; Chung, S.; Park, C.W.; Chang, Y.S.; Shin, S.J. Association of blood manganese level with diabetes and renal dysfunction: A cross-sectional study of the Korean general population. BMC Endocr. Disord. 2014, 8, 14-24.

66. Rambouskova, J.; Krskova, A.; Slavikova, M.; Cejchanova, M.; Wranova, K.; Prochazka, B.; Cerna, M. Trace elements in the blood of institutionalized elderly in the Czech Republic. Arch. Gerontol. Geriatr. 2013, 56, 389-394.

67. Flores, C.R.; Puga, M.P.; Wrobel, K.; Sevilla, M.E.G.; Wrobel, K. Trace elements status in diabetes mellitus type 2: Possible role of the interaction between molybdenum and copper in the progress of typical complications. Diabetes Res. Clin. Pract. 2011, 91, 333-341.

68. Czernichow, S.; Vergnaud, A.C.; Galan, P.; Arnaud, J.; Favier, A.; Faure, H.; Huxley, R.; Hercberg, S.; Ahluwalia, N. Effects of long-term antioxidant supplementation and association of serum antioxidant concentrations with risk of metabolic syndrome in adults. Am. J. Clin. Nutr. 2009, 90, 329-335.

(C) 2015 by the authors; licensee MDPI, Basel, Switzerland. This article is an open access article distributed under the terms and conditions of the Creative Commons Attribution license (http://creativecommons.org/licenses/by/4.0/). 